\title{
The impact of wildfire on microbial C:N:P stoichiometry and the fungal-to-bacterial ratio in permafrost soil
}

\author{
Xuan Zhou • Hui Sun · Jukka Pumpanen • Outi-Maaria Sietiö • \\ Jussi Heinonsalo $\cdot$ Kajar Köster · Frank Berninger
}

Received: 22 January 2018/ Accepted: 4 October 2018/Published online: 28 October 2018

(C) The Author(s) 2018

\begin{abstract}
Wildfires thaw near-surface permafrost soils in the boreal forest, making previously frozen organic matter available to microbes. The short-term microbial stoichiometric dynamics following a wildfire are critical to understanding the soil element variations in thawing permafrost. Thus, we selected a boreal wildfire chronosequence in a region of continuous permafrost, where the last wildfire occurred 3 , 25,46 , and $>100$ years ago (set as the control) to explore the impact of wildfire on the soil chemistry, soil microbial stoichiometry, and the fungal-to-bacterial gene ratio ( $\mathrm{F}: \mathrm{B}$ ratio). We observed the microbial biomass $\mathrm{C}: \mathrm{N}: \mathrm{P}$ ratio remained constant in distinct age
\end{abstract}

Responsible Editor: John Harrison.

Electronic supplementary material The online version of this article (https://doi.org/10.1007/s10533-018-0510-6) contains supplementary material, which is available to authorized users.

X. Zhou $(\bowtie) \cdot$ J. Heinonsalo $\cdot$ K. Köster $\cdot$ F. Berninger Department of Forest Sciences, University of Helsinki, P.O. Box 27, 00014 Helsinki, Finland

e-mail: xuan.zhou@helsinki.fi

\section{H. Sun}

Collaborative Innovation Center of Sustainable Forestry in China, College of Forestry, Nanjing Forestry

University, Nanjing 210037, China

J. Pumpanen

Department of Environmental and Biological Sciences, University of Eastern Finland, 70211 Kuopio, Finland classes indicating that microbes are homeostatic in relation to stoichiometric ratios. The microbial C:N ratios were independent of the shifts in the fungal-tobacterial ratio when $\mathrm{C}: \mathrm{N}$ exceeded 12 . Wildfireinduced reduction in vegetation biomass positively affected the fungal, but not the bacterial, gene copy number. The decline in microbial biomass $\mathrm{C}, \mathrm{N}$, and $\mathrm{P}$ following a fire, primarily resulted from a lack of soil available $\mathrm{C}$ and nutrients. Wildfire affected neither the microbial biomass nor the $\mathrm{F}: \mathrm{B}$ ratios at a soil depth of $30 \mathrm{~cm}$. We conclude that microbial stoichiometry does not always respond to changes in the fungal-tobacterial ratio and that wildfire-induced permafrost thawing does not accelerate microbial respiration.

Keywords Wildfire - Boreal forest - Permafrost . Microbial biomass - C:N:P stoichiometry · Homeostasis · Fungal-to-bacterial ratio

O.-M. Sietiö · J. Heinonsalo

Department of Food and Environmental Sciences, University of Helsinki, P.O. Box 56, 00014 Helsinki, Finland

X. Zhou · J. Heinonsalo · K. Köster · F. Berninger Institute for Atmospheric and Earth System Research/ Forest Sciences, Faculty of Agriculture and Forestry, University of Helsinki, Helsinki, Finland

J. Heinonsalo

Finnish Meteorological Institute, Climate System Research, P.O. Box 503, 00101 Helsinki, Finland 


\section{Introduction}

Soil microbes play a crucial role in carbon (C), nitrogen $(\mathrm{N})$, and phosphorus $(\mathrm{P})$ cycling in terrestrial ecosystems by mineralizing organic material to inorganic forms (Singh et al. 2010; Waring et al. 2013; Xu et al. 2013). Researchers have shown that the efficiency of microbial decomposition and mineralization strongly depends on the stoichiometry of the microbes themselves and that of the resources (Schimel and Bennett 2004; Mooshammer et al. 2012). Ecological stoichiometry has been used for decades to link the elemental composition of organisms to their environment (Redfield 1958; Sterner and Elser 1992), and only recently adopted for use in terrestrial ecosystems (Cleveland and Liptzin 2007; $\mathrm{Xu}$ et al. 2013). Identical stoichiometric ratios in microbes and their surrounding environments were first reported in marine ecosystems (Redfield 1958; Redfield et al. 1963). However, in contrast to marine ecosystems, a meta-analysis of the soil microbial stoichiometry on a global scale indicated that soil microbes might maintain their internal $\mathrm{C}: \mathrm{N}: \mathrm{P}$ ratio regardless of their environment (Cleveland and Liptzin 2007; Xu et al. 2015).

Microbes tend to maintain their chemical elements in "optimal ratios" for growth and development (Sterner and Elser 2002). They maintain these ratios by releasing excess elements through respiration or excretion (Tempest and Neijssel 1992) or by obtaining deficient elements through excretion of extracellular enzymes (Mooshammer et al. 2014). Therefore, stoichiometric ratios in both decomposers and their resources affect the decomposition process. Homeostasis refers to the ability of an organism to maintain an internal elemental ratio despite a changing environment (Sterner and Elser 2002). Strictly homeostatic organisms maintain internal nutrient concentration ratios (e.g., C:N:P ratios) independent of their resource's stoichiometry, whereas non-homeostatic organisms depend upon it.

The soil microbial $\mathrm{C}: \mathrm{N}: \mathrm{P}$ ratios vary between different biomes despite the tendency towards the homeostasis of soil microbes (Xu et al. 2013). This phenomenon may be caused by shifts in the microbial

\section{F. Berninger}

The Nurturing Station for the State Key Laboratory of Subtropical Silviculture, Zhejiang A \& F University, Lin'an 311300, Zhejiang, China community composition (Mouginot et al. 2014) or by changes in the soil nutrient supply (Wilkinson 1963; Cleveland and Liptzin 2007; Griffiths et al. 2012). For example, fungal biomass has a higher $\mathrm{C}: \mathrm{N}$ ratio than bacterial biomass (Strickland and Rousk 2010; Mouginot et al. 2014). A higher fungal-to-bacterial (F:B) ratio may, therefore, be associated with a higher $\mathrm{C}: \mathrm{N}$ ratio for the total microbial biomass. Variation in the microbial stoichiometry under natural conditions or under disturbances caused by additional nutrients has been well studied (Cleveland and Liptzin 2007; Heuck et al. 2015; Midgley and Phillips 2016; Zhou et al. 2017), but its response to a rapid decline in nutrient availability remains insufficiently understood. It is also unclear how soil microbial community compositions react to rapid changes in the substrate stoichiometry and whether these community compositions can maintain homeostasis under variable conditions.

Wildfire is one of the most significant disturbances in nature (Schuur et al. 2008; Taş et al. 2014), with about $1 \%$ of all boreal forests exposed to wildfire annually (Kasischke and Stocks 2000). Wildfire burns off a massive amount of $\mathrm{C}$ and converts soil organic nutrients into inorganic forms (Harden et al. 2004; Wan et al. 2001); increase soil temperature (Liu et al. 2005; Treseder et al. 2012) and soil pH (Högberg et al. 2007); and decrease soil moisture above the permafrost layer (Debano 2000). However, it also converts soil organic $\mathrm{C}$ to charcoal and other pyrogenic compounds, which are relatively more resistant to microbial decomposition (González-Pérez et al. 2004; Knicker 2007). These changes also lead to an increase in the thickness of the active layer above the permafrost exposing previously frozen organic matter to decomposition via soil microbes (Taş et al. 2014). Furthermore, wildfire changes the soil microbial community composition (Allison et al. 2013; Sun et al. 2015), because fungi are more sensitive to heat and a high $\mathrm{pH}$ than bacteria (Bååth et al. 1995; Bárcenas-Moreno and Bååth 2009). In addition, wildfire reduces the richness and diversity of mycorrhizal fungi by destroying the tree and shrub vegetation upon which ectomycorrhizal fungi rely (Jonsson et al. 1999; Peay et al. 2009; Sun et al. 2015).

Indeed, previous studies demonstrated dynamic changes over time following a fire in the microbial community structure, soil enzyme activity, and soil chemistry (Holden et al. 2013; Köster et al. 2016; Knelman et al. 2014, 2017). This study, however, 
attempts to demonstrate the relationships between these factors varying over time following a fire. Thus, we tested the effect of the soil quality (i.e., bioavailable $\mathrm{C}, \mathrm{N}$, and $\mathrm{P}$ ) and microclimate (e.g., soil temperature, and moisture) on the soil microbial stoichiometric ratios and the homeostatic degree along a fire chronosequence. We hypothesized that (i) the microbial biomass in the deep soil layer increases after a wildfire because fire releases the organic matter for microbes; (ii) wildfire-induced soil changes in both the top layer and the soil near the permafrost lead to less constrained the microbial stoichiometric ratios and a lack of the homeostatic regulation; and (iii) the plasticity of the microbial stoichiometry is related to the fungal-to-bacterial ratio. We tested these hypotheses in natural conditions in a chronosequence of boreal forest stands exposed to wildfire 3 to $>100$ years ago. These forest stands grow on permafrost at different stages of vegetation succession and allow us to test the effect of wildfire on the microbial community and soil nutrient availability in a unique way. In what follows, we explain the changes in the microbial biomass and the microbial $\mathrm{C}: \mathrm{N}: \mathrm{P}$ stoichiometric ratios based on the time since the last wildfire, vegetation biomass, permafrost depth, soil extractable $\mathrm{C}, \mathrm{N}$, and $\mathrm{P}$ contents, $\mathrm{F}: \mathrm{B}$ ratios, and soil $\mathrm{CO}_{2}$ effluxes described as the biological activity in the soil.

\section{Materials and methods}

Site description

Our study sites were located near Eagle Plains in the Yukon $\left(66^{\circ} 22^{\prime} \mathrm{N}, 136^{\circ} 43^{\prime} \mathrm{W}\right)$ and Tsiigehtchic in the Northwest Territories $\left(67^{\circ} 26^{\prime} \mathrm{N}, 133^{\circ} 45^{\prime} \mathrm{W}\right)$, Canada. This region lies in the subarctic climate zone, which is characterized by a long, cold winter and a short hot summer, with monthly average temperatures ranging from $-28{ }^{\circ} \mathrm{C}$ in winter to $20^{\circ} \mathrm{C}$ in summer (World Weather Online, 2016). The annual precipitation of northern Yukon and Tsiigehtchic along low-elevation valley floors is only $250-300 \mathrm{~mm}$ (World Weather Online 2016). The dominant tree species are black spruce (Picea mariana (Mill.) Britton, Sterns and Poggenburg), and white spruce (Picea glauca (Moench) Voss), and dominate dwarf shrubs are lingonberry (Vaccinium vitis-ideaa L.), cloudberry
(Rubus chamaemorus L.), blueberry (Vaccinium uliginosum L.), and Rhododendron groenlandicum Oeder.. The ground vegetation include mosses and lichen species such as Sphagnum sp., Cladonia sp., and Cladina sp (Köster et al. 2017). The soil in the area belongs to the Cryosolic Order (Stanek 1982). The bedrock consists of a Cretaceous sandstone overlain by ice-rich fluvial and clay-rich colluvial deposits underlain by continuous permafrost (Yukon Ecoregions Working Group, 2004). The areas were not glaciated during the last ice age (Yukon Ecoregions Working Group 2004).

This study was conducted in areas where the last fire occurred in 3, 25, 46, and more than 100 (set as the control) years ago. The chronosequence consisted of similar forest stands on clay with underlying permafrost and climatic conditions, but different soil micro-climatic conditions as well as living tree and ground vegetation coverage since the last wildfire (Fig. 1). We selected the chronosequence using a twostage process. We first selected forest areas from a GIS map of burned areas (Government of Yukon 2011). The selection criteria consisted of accessibility (distance of less than $1 \mathrm{~km}$ from the road) and age after a fire. We excluded the sites burned twice since 1950 . During fieldwork, we narrowed down sites using additional criteria, consisting of the soil type (clay), topography (flat or gentle slopes of less than 10\%), tree species before fire (black or white spruce), and tree diameter at breast height (DBH). The ages of the control areas were confirmed by coring and counting tree rings (which lead to ages over 100 years for all areas assuming that it takes 25 years to reach DBH in these areas). The tree DBH of snags that predating the fires were compared with those of the control areas (Table S1). Dead trees were measured without bark in the burned areas, forcing us to estimated the bark thickness based on the following equation from Schneider (2007): Bark thickness ${ }_{i}=2 \times(0.3640+$ $0.0351 \mathrm{DBH}_{i}-0.00003 \mathrm{DBH} \mathrm{H}_{i}^{2}$. All the sampling sites were located within the continuous permafrost zone, with $90-100 \%$ of the ground underlain by permafrost (Yukon Ecoregions Working Group 2004). Forests in these areas are not and have never been managed commercially. 

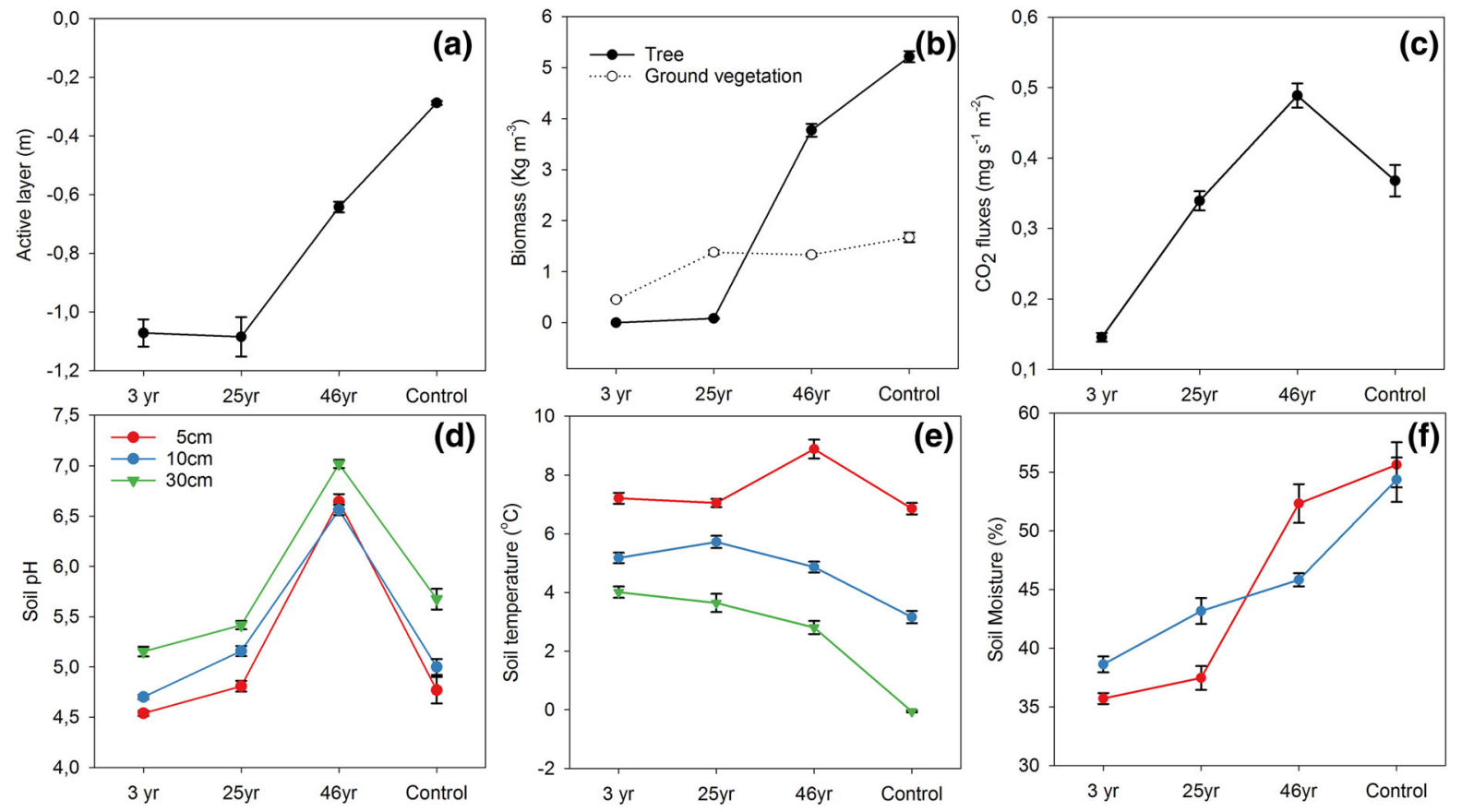

Fig. 1 a Permafrost active layer thickness. b Tree and ground vegetation biomass in each area. $\mathrm{CO}_{2}$ fluxes measured from the soil surface. $\mathbf{d}-\mathbf{f}$ The $\mathrm{pH}$, temperature, and moisture content of each soil layer. The soil moisture content was not measured at a

Biomass and soil sampling

All data used in this study were collected during an intensive measurement campaign conducted in July and August 2015. We employed a hierarchical sampling strategy because site access and time imposed tight constraints. Nine $400-\mathrm{m}^{2}$ sample plots were set up per age class, and these plots were located 50-m apart on three 160-m-long sampling lines separated by at least $200 \mathrm{~m}$. To ensure the control area was representative, each control line was placed in an unburned forest nearby each burned area (see the map from Köster et al. 2017). The sampling lines were placed at least $150 \mathrm{~m}$ away from the roads to avoid possible unintended road effects on the vegetation or permafrost depth (Gill et al. 2014). In addition, the sample plots were placed on relatively flat terrain to minimize the topographical effects. The characteristics of all trees (starting with those $1 \mathrm{~m}$ in height) inside the sample plots were measured (the stem diameter at $1.30-\mathrm{m}$ high, the height of the tree, the crown height and diameter). The ground vegetation biomass was measured in four $0.20 \times 0.20$-m squares depth of $30 \mathrm{~cm}$ because the soil samples were saturated with water. Each data point consists of a mean and standard error $($ mean $\pm \mathrm{SE})$

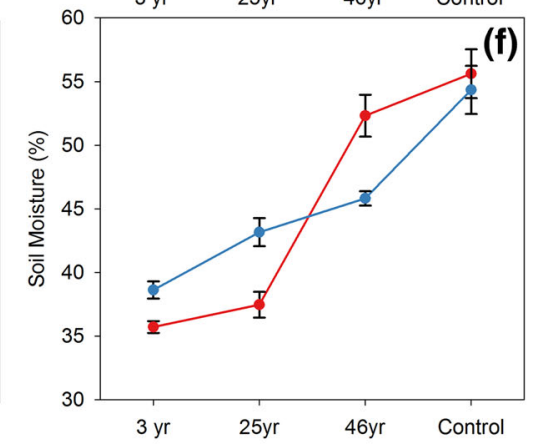


following a wildfire. Hence, in this study, we utilized the years after a fire as the causal factors associated with changes in the microbial biomass, as well as in the fungal and bacterial composition. In this study, active layer depths decreased across successive years from about 2 to $0.28 \mathrm{~m}$. In the control area, the deepest soil layer sampled $(0.30 \mathrm{~m})$ was within the permafrost layer (Fig. 1).

The soil temperature, moisture, carbon dioxide $\left(\mathrm{CO}_{2}\right)$ fluxes, vegetation properties and the thickness of the active layer above the permafrost table were recorded in each plot (Fig. 1). The thickness of the active layer was estimated as the distance between soil surface and the ice layer. In areas where the active layer was more than $1.2 \mathrm{~m}$ and digging was impossible, we estimated the permafrost depths using a linear regression model of the temperature in the mineral soil against the depths. The soil $\mathrm{CO}_{2}$ flux was measured at the same time as soil sampling using metal collars $(0.21-\mathrm{m}$ in diameter and $0.05-\mathrm{m}$ in height), 18 collars per fire age area ( 2 collars $\times 3$ plots $\times 3$ lines). The $\mathrm{CO}_{2}$ flux was measured with an opaque cylindrical chamber (height of 0.24-m and diameter of 0.20-m) equipped with a $\mathrm{CO}_{2}$ sensor (GMP343, Vaisala Oyj, Helsinki, Finland), relative humidity, and temperature sensor (HMP75, Vaisala Oyj, Helsinki, Finland) as previously described (Köster et al. 2017). The soil's water content was measured using a soil moisture sensor (Thetaprobe ML2x, Delta-T Devices Ltd, Cambridge, UK) connected to a data reader (HH2 moisture meter, Delta-T Devices Ltd, Cambridge, UK).

Soil and microbial biomass $\mathrm{C}, \mathrm{N}$, and $\mathrm{P}$ measurements

Visible plant roots were removed from soil samples before homogenization. The total soil $\mathrm{C}$ and $\mathrm{N}$ were determined with an elemental analyser (Vario MAX C\&N analyser, Elementar Ltd., UK). We used the chloroform fumigation extraction (CFE) method to estimate soil microbial biomass $\mathrm{C}, \mathrm{N}$, and $\mathrm{P}$ contents (Hedley and Stewart 1982; Brookes et al. 1985; Beck et al. 1997). A 3-g dry weight (d.w.) equivalent of soil was fumigated at $25{ }^{\circ} \mathrm{C}$ with ethanol-free chloroform for $24 \mathrm{~h}$ and extracted using 0.5- $\mathrm{M} \mathrm{K}_{2} \mathrm{SO}_{4}$ (for $\mathrm{C}$ and $\mathrm{N}$ ) or $0.5-\mathrm{M} \mathrm{NaHCO}_{3}$ with $\mathrm{pH}$ of 8.5 (for P) (Olsen et al. 1954). Before fumigation, soil samples were incubated for 7-10 days at $4{ }^{\circ} \mathrm{C}$. Non-fumigated soils were extracted in the same way. Extracts were filtered through $0.45-\mu \mathrm{m}$ syringe filters before the analysis. The soil organic $\mathrm{C}$ and $\mathrm{N}$ were measured using a total organic C analyser (Shimadzu TOC-V CPH, Shimadzu Corp., Kyoto, Japan). Inorganic phosphorus was measured using the ammonium molybdate-malachite green method on a 96-well microplate (D'Angelo et al. 2001). The difference in the total organic $\mathrm{C}$ content between the fumigated and non-fumigated samples was taken as the soil microbial biomass. The conversion factors, also known as the extraction efficiency, for estimating the microbial biomass C, $\mathrm{N}$, and $\mathrm{P}$ were $0.45,0.54$ (Beck et al. 1997), and 0.40 (Brookes et al. 1982), respectively. Organic C and N, and inorganic $\mathrm{P}$ measured from the soil extracts of non-fumigated samples were considered soil-extractable $\mathrm{C}\left(C_{e x t}\right), \mathrm{N}\left(N_{e x t}\right)$, and $\mathrm{P}\left(P_{e x t}\right)$.

DNA extraction and quantitative PCR

To determine the F:B ratio, DNA was extracted from 0.1 -g fresh weight (f.w.) topsoil (at depths of $0.05 \mathrm{~m}$ and $0.10 \mathrm{~m}$ ) and from $0.2 \mathrm{~g}$ f.w. in $0.30 \mathrm{~m}$ depth using the NucleoSpin Soil DNA extraction kit (Macherey-Nagel $\mathrm{GmbH} \& \mathrm{Co}$ ) according to the manufacturer's instructions. The samples were homogenized using the FastPrep-24 Instrument (MP Biomedicals) at $5 \mathrm{~m} \mathrm{~s}^{-1}$ for $30 \mathrm{~s}$ using the ceramic bead tubes provided with the bulkbeads. The extracted DNA was further purified using the PowerClean Pro DNA Clean-Up Kit (MO BIO Laboratories). The nucleic acid concentrations of the processed samples were measured with a NanoDrop spectrophotometer (Thermo Scientific) at $260 \mathrm{~nm}$.

Fungal 18S ribosomal RNA (rRNA) and bacterial 16S rRNA sequences were determined by quantitative PCR (qPCR) using target-specific primer pairs: FF390 (5'-ATTACCGCGGCTGCTGG-3') and FR1 (5'-AICCATTCAATCGGTAIT-3') (Vainio and Hantula 2000) for fungi, and Eub338F ( $5^{\prime}$-ACTCCTACGGGAGGCAGCAG-3') and Eub518R (5'ATTACC GCGGCTGCTGG-3') (Fierer and Jackson 2005) for bacteria. qPCR was carried out using a Bio-Rad CFX96 iCycler on 96-well white-welled polypropylene plates (Bio-Rad) as previously described (Helin et al. 2017). Briefly, the reaction mixture contained a $1 \times$ SsoAdvanced universal SYBR Green Supermix (Bio-Rad, USA), 0.3-0.6 ng of template DNA, $250 \mathrm{nM}$ of Eub338F and Eub518R primers for bacteria, or 3-6 ng of template DNA, $250 \mathrm{nM} \mathrm{FF390} \mathrm{and}$ 
$200 \mathrm{nM}$ FR1 primers for fungi with the reaction volume set to $20 \mu \mathrm{l}$ using nuclease-free water. The qPCR reactions were conducted using combined annealing and extension at $55{ }^{\circ} \mathrm{C}$ for $30 \mathrm{~s}$ for bacteria over 35 cycles and $60{ }^{\circ} \mathrm{C}$ for $60 \mathrm{~s}$ for fungi over 45 cycles. Fluorescence was measured during the elongation step. After the PCR run, we conducted a melt curve analysis for the products from 65 to $95{ }^{\circ} \mathrm{C}$ by raising the temperature of $0.5{ }^{\circ} \mathrm{C}$ per $5 \mathrm{~s}$.

We generated standard curves using DNA extracted from Escherichia coli H673 (HAMBI culture collection, University of Helsinki, Finland) for the bacterialspecific qPCR reaction. DNA extracted from Phlebia radiata FBCC43 (genome size $40.92 \mathrm{Mb}$, FBCC culture collection, University of Helsinki, Finland) was used for the fungal-specific qPCR reactions (Kuuskeri et al. 2016).

Data analysis

We studied the variation in the microbial biomass, F:B ratios, and the environmental factors affecting them using an analysis of variance. Data was first checked for the normality and homogeneity of variances using the Shapiro-Wilk and Levene's tests (Shapiro and Wilk 1965; Brown and Forsythe 1974). Data that failed to pass these tests were log-transformed before we run the analysis of variance. However, data presented in Figs. 2 and 3 represent the original data to facilitate comparison with other studies.

The effects of wildfire as well as the soil and vegetation properties on the microbial biomass and $\mathrm{F}: \mathrm{B}$ ratios were determined using linear mixed-effect models. In cases where the predictable variables had multicollinearity with each other, variables with variance inflation factors (VIF) of less than 3 were retained in the initial model (James et al. 2000). We measured the following variables: years after a wildfire $\left(Y_{\text {fire }}, y r\right)$, depth of the soil active layer $\left(D_{\text {active }}, \mathrm{m}\right)$, depth of the soil sample (Depth, $m$ treated as a class variable), tree biomass $\left(B_{\text {tree }}, \mathrm{kg} \mathrm{m}^{-3}\right)$ and ground vegetation biomass $\left(B_{g r}, \mathrm{~kg} \mathrm{~m}^{-3}\right)$, the soil $\mathrm{CO}_{2}$ effluxes measured from the soil surface $\left(\mathrm{CO}_{2}, \mathrm{mg} \mathrm{m}^{-2}\right.$ $\left.\mathrm{s}^{-1}\right)$, soil $\mathrm{pH}(\mathrm{pH})$, soil temperature $\left(T_{\text {soil }},{ }^{\circ} \mathrm{C}\right)$ and moisture $\left(M_{\text {soil }}, \%\right)$ for each layer, the total soil $\mathrm{C}\left(C_{\text {total }}\right)$ and $\mathrm{N}\left(N_{\text {total }}\right)$, soil-extractable organic $\mathrm{C}$ $\left(C_{\text {ext }}, \mathrm{mg} \mathrm{g}^{-1}\right)$, soil-extractable organic $\mathrm{N}\left(N_{\text {ext }}\right.$, $\left.\mathrm{mg} \mathrm{g}^{-1}\right)$, and soil-extractable inorganic $\mathrm{P}\left(P_{\text {ext }}\right.$, $\left.\mathrm{mg} \mathrm{g}^{-1}\right)$. Before fitting the model, we tested whether total soil elements or soil-extractable elements were better predictors (described in the supplementary material). We detected that the soil-extractable elements predicted the microbial biomass $\mathrm{C}, \mathrm{N}$, and $\mathrm{P}$ better than the total soil elements (Table S2, Models S2, and S4). Therefore, we removed the total soil elements as explanatory variables. Furthermore, since $D_{\text {active, }} B_{g r}, T_{\text {soil }}$, and $M_{\text {soil }}$ were highly correlated with $Y$ and Depth (see Fig. S1), these were excluded from the initial model to prevent collinearity. Therefore, the initial mixed-effect model only included $Y$, Depth, $p H$, $\mathrm{CO}_{2}, \mathrm{C}_{\text {ext }}, \mathrm{N}_{\text {ext }}$, and $\mathrm{P}_{\text {ext }}$ as fixed effects, while the sampling lines were treated as a random effect $(\beta)$. Thus, the initial model including all of the noncollinearity explanatory variables was as follows:

$$
\begin{aligned}
M_{X_{i j}}= & a+b Y_{i j}+c \text { Depth }_{i j}+d p H_{i j}+e C O_{2 i j} \\
& +f C_{e x t i j}+g N_{e x t i j}+h P_{e x t i j}+\beta_{i}+\varepsilon_{i j}
\end{aligned}
$$

To calculate the degree of homeostasis in the microbes, we used the classical method by fitting the data to the homeostatic model (Sterner and Elser 2002). However, instead of fitting a linear regression, we conducted the analysis using the mixed-effect model as follows:

$\log _{e}(y)=c+\frac{1}{H} \log _{e}\left(x_{i j}\right)+\beta_{i}+\varepsilon_{i j}$

where $y$ is the element content or molar ratio of the microbial biomass, $x$ is the extractable element content or ratio in the soil, and $c$ is a constant. $H$ represents the degree of homeostasis, $\beta$ the random effect based on sampling lines, and $\varepsilon$ the residual of the model. The higher the $H$ is, the stronger is the microbial homeostatic regulation against the soil nutrient supply.

In addition, we analysed the potential effect of the fungal-to-bacterial biomass ratios on the microbial $\mathrm{C}: \mathrm{N}$ ratios, assuming that the $\mathrm{C}: \mathrm{N}$ ratio of fungi was 16 and the $\mathrm{C}: \mathrm{N}$ ratio of bacteria was 6 (Wallenstein et al. 2006; Waring et al. 2013). We then calculated the total microbial $\mathrm{C}: \mathrm{N}$ ratio as:

Microbial C:N ratio

$$
=\frac{\text { fungal biomass }+ \text { bacterial biomass }}{\frac{\text { fungal biomass }}{16}+\frac{\text { bacterial biomass }}{6}}
$$

where bacterial biomass $=\frac{\text { Fungal biomass }}{F: \text { B ratio }}$. 

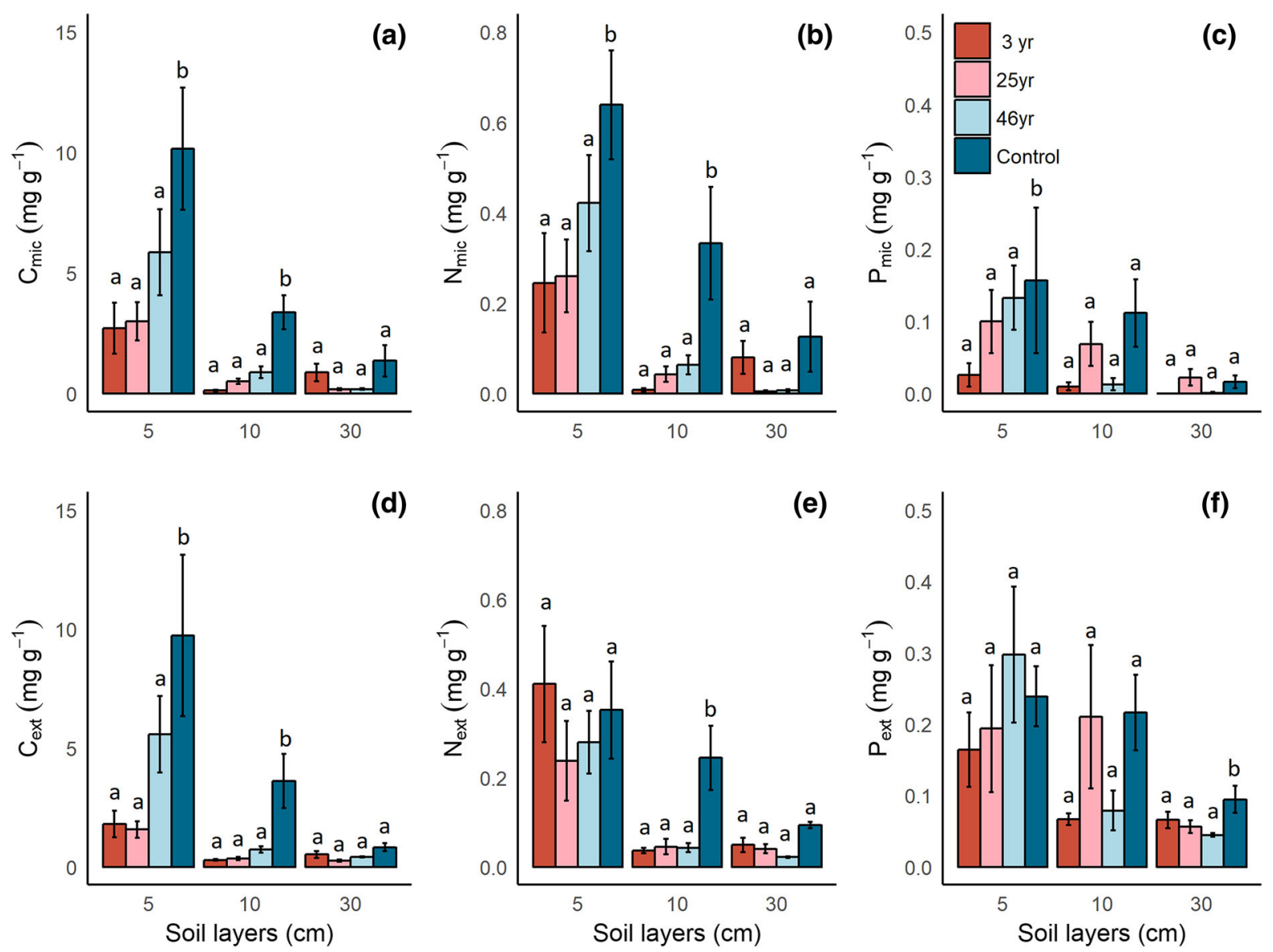

Fig. 2 Size of microbial biomass $\mathrm{C}$ content $\left(C_{\text {mic }}\right)(\mathbf{a}), \mathrm{N}$ content $\left(N_{\text {mic }}\right)(\mathbf{b}), \mathrm{P}$ content $\left(P_{\text {mic }}\right)(\mathbf{c})$, soil-extractable $\mathrm{C}$ content $\left(C_{\text {ext }}\right)(\mathbf{d}), \mathrm{N}$ content $\left(N_{\text {ext }}\right)(\mathbf{e})$, and $\mathrm{P}$ content $\left(P_{\text {ext }}\right)(\mathbf{f})$. Samples were collected from three soil depths $(5,10$ and 30$)$ on a chronosequence following a forest fire. The error bars

In doing so, we estimated the possible effects (or the lack of effects) of changing the fungal-to-bacterial ratios on the microbial $\mathrm{C}: \mathrm{N}$ ratio, although the real fungal-to-bacterial biomass ratios in our data remained unknown.

All statistical analyses were conducted using $\mathrm{R}$ (RStudio, Inc., 2009-2016), making specific use of the "vegan" (Oksanen et al. 2017), "ggplot2" (Wickham 2009), "lme4" (Betes et al. 2015), and "lattice" (Sarkar 2008) packages. The mixed-effect model was fitted using the "lme4" package, and we used the "drop1" function (Chambers and Hastie 1992) to select the best model. Individual variables were removed from the model by using the "drop1" function in each run until the lowest Akaike's represent the standard errors. Statistically significant differences $(p<0.05)$ compared within each soil layer are denoted with different letters above the bars. The data were log-transformed before performing the variance test. However, the values shown here consist of the untransformed data

Information Criterion (AIC) value was achieved (Akaike 1998). This final model was considered to be the best model. We set the statistical significance level at $p<0.05$.

\section{Results}

Soil and vegetation characterization

The thickness of the soil active layer decreased with the age of the forest stand from $1.03 \mathrm{~m}$ in the recently burned areas to $0.28 \mathrm{~m}$ in the control areas (Fig. 1a). The living tree biomass increased during the forest succession from $0 \mathrm{~kg} \mathrm{~m}^{-2}$ in areas where a wildfire occurred 3 years previously to $5 \mathrm{~kg} \mathrm{~m}^{-2}$ in the control 
Fig. 3 Boxplots of (a) the fungal-to-bacterial (F:B) gene copy number ratio and $\mathbf{b}, \mathbf{c}$ the gene copy number of the fungal and bacterial genomic DNA along successional years following a fire at each soil depth. Statistical significances for each soil layer are marked with distinct letters above the upper quantile lines. The original data are shown here, but the data were logtransformed before the variance analyses. Solid lines in the middle of the boxes represent the 50 th percentile (median), and the box represents the limits for 25 th and 75 th percentiles
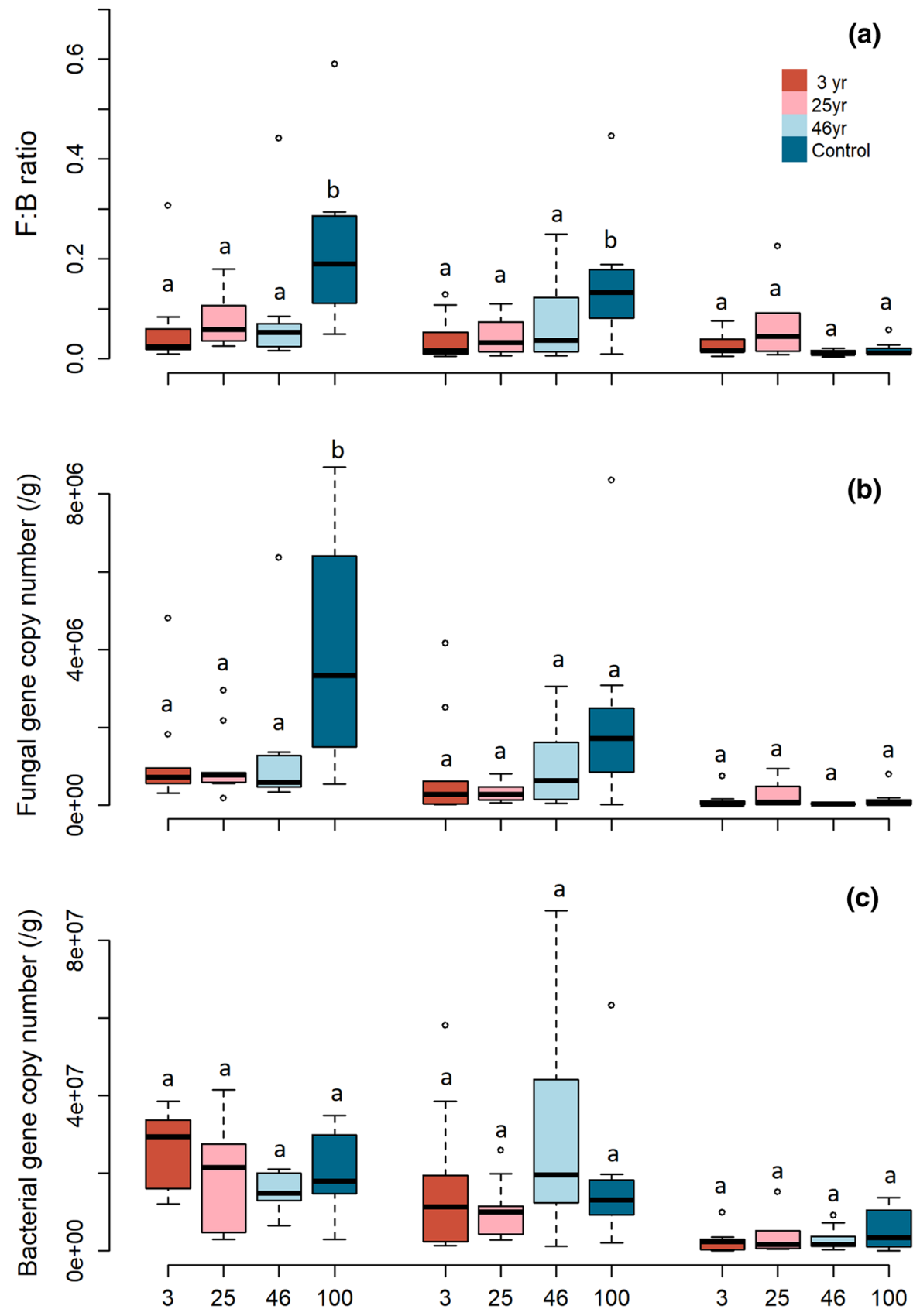

area (Fig. 1b). The soil $\mathrm{CO}_{2}$ efflux also increased from $0.14 \mathrm{mg} \mathrm{m}^{-2} \mathrm{~s}^{-1} 3$ years following a wildfire to $0.47 \mathrm{mg} \mathrm{m}^{-2} \mathrm{~s}^{-1} 46$ years following a wildfire, then declined to $0.37 \mathrm{mg} \mathrm{m}^{-2} \mathrm{~s}^{-1}$ in the control area (Fig. 1c).

The average $\mathrm{pH}$ in all soil layers was the highest 46 years after a wildfire, while no differences were observed between the other age classes (Fig. 1d). The soil temperatures in the topsoil were similar across the age classes, but were decreased in 10 and $30 \mathrm{~cm}$ layers across the time elapsed since the wildfire (Fig. 1e). The soil moisture content at the depths of 5 and $10 \mathrm{~cm}$ increased with the number of years since the last wildfire, from $35 \% 3$ years after a wildfire to $55 \%$ in the control area (Fig. 1f). The soil was saturated with water at a depth of $30 \mathrm{~cm}$ in burned areas but remained 
frozen in the control area. Therefore, the soil water contents in the $30 \mathrm{~cm}$ soil layer are not shown, because the soil moisture sensor measures the dielectricity, which is unreliable when the water is frozen.

\section{$\mathrm{C}, \mathrm{N}$, and $\mathrm{P}$ in soil and microbial biomass}

The total $\mathrm{C}$ content in all soil layers was significantly higher in the control area than that in the burned areas (Fig. S2a), decreasing with the soil depth (Fig. S2a). Apart from the higher total soil $\mathrm{N}$ content at $5 \mathrm{~cm}$ depth in the 46-year-old area, we found no significant difference across the remaining age classes (Fig. S2b). The extractable-organic $\mathrm{C}\left(C_{\text {ext }}\right)$ content at depths of 5 and $10 \mathrm{~cm}$ was significantly higher $(p<0.003)$ in the control area than in the younger age classes (Fig. 2d), increasing from $1.9 \pm 0.2$ to $9.7 \pm 1.4 \mathrm{mg} \mathrm{g}^{-1}$ at 5 -cmdeep and from $0.3 \pm 0.01$ to $3.6 \pm 0.4 \mathrm{mg} \mathrm{g}^{-1}$ at $10 \mathrm{~cm}$; we found no statistical difference in $C_{\text {ext }}$ across age classes at 30 -cm-deep. We also found no difference in the extractable organic $\mathrm{N}\left(N_{\text {ext }}\right)$ at 5 and $30 \mathrm{~cm}$ across age classes, while $N_{\text {ext }}$ at 10 -cm-deep were significant higher in the control site than younger sites $(p<0.02)$ (Fig. 2e). Likewise, the soil-extractable $\mathrm{P}$ contents at a depth of 5 and $10 \mathrm{~cm}$ revealed no difference across age classes, while they were significantly higher in the oldest age class than in the younger ones at 30-cm-deep $(p<0.02)$ (Fig. 2f). The soil-extractable $\mathrm{C}, \mathrm{N}$, and $\mathrm{P}$ decreased with the soil depth (Fig. 2d-f).

We also identified clear increasing trends in the microbial biomasses $\mathrm{C}, \mathrm{N}$, and $\mathrm{P}$ with the age of fires (Fig. 2). The microbial biomass $\mathrm{C}$ increased from 3.5 $\pm 0.5 \mathrm{mg} \mathrm{g}^{-1}$ in the youngest age class to $10.1 \pm$ $0.7 \mathrm{mg} \mathrm{g}^{-1}$ in the control site, while the microbial biomass increased from $0.13 \pm 0.01$ to $3.4 \pm$ $0.25 \mathrm{mg} \mathrm{g}^{-1}$ at a depth of $10 \mathrm{~cm}$ (Fig. 2a). The microbial biomass $\mathrm{N}$ content was significantly higher in the control area than that in the younger age classes ranging from $0.10 \pm 0.01$ to $0.37 \pm 0.02 \mathrm{mg} \mathrm{g}^{-1}$ at $5 \mathrm{~cm}$ and from $0.01 \pm 0.001$ to $0.4 \pm 0.05 \mathrm{mg} \mathrm{g}^{-1}$ at $10 \mathrm{~cm}$ (Fig. 2b). We found a significant difference in microbial biomass $\mathrm{P}$ between the control and the youngest age classes at a depth of $5 \mathrm{~cm}$, where it ranged from $0.009 \pm 0.001 \mathrm{mg} \mathrm{g}^{-1}$ in the youngest age class to $0.23 \pm 0.03 \mathrm{mg} \mathrm{g}^{-1}$ in the control (Fig. 2c). Microbial biomass $\mathrm{P}$ was around zero at a depth of $30 \mathrm{~cm}$, since the $P$ content in the microbes was likely below the detection limit.
Correlation between microbial biomass and soil properties

Wildfire caused a sequestration of charcoal and recalcitrant organic matter in the humus layer which is unavailable to microbes (Johnson and Curtis 2001). Thus, elements in dissolved form appear crucial to microbial stoichiometry (Fanin et al. 2013). Here, we used the soil-extractable element contents as explanatory variables in the linear mixed-effect model, finding that they explained the soil microbial biomass better than total soil element contents (Table S2).

In addition, soil-extractable organic $\mathrm{C}$ and $\mathrm{P}$ explained $76 \%$ of the variation in microbial biomass $\mathrm{C}$ (Model 2, Table 1). The soil pH, depth, and soilextractable $\mathrm{C}$ and $\mathrm{P}$ explained $70 \%$ of the variation in microbial biomass $\mathrm{N}$ (Model 2, Table 1). Interestingly, the soil-extractable $\mathrm{N}$ alone explained $41 \%$ of the variation in microbial biomass $\mathrm{P}$ (Model 3, Table 1).

\section{$\mathrm{C}: \mathrm{N}: \mathrm{P}$ stoichiometry in soil and microbial biomass}

The soil-extractable C:N $\left(C: N_{\text {ext }}\right)$ at depths of 5 and $10 \mathrm{~cm}$ increased over time since the last wildfire, emerging as significantly higher at $30 \mathrm{~cm}$ depth in 46 years following a wildfire than in the other age classes (Table 2). Apart from the increasing soil extractable $\mathrm{C}: \mathrm{P}$ ratios $\left(C: P_{\text {ext }}\right)$ at $5 \mathrm{~cm}$, we observed no differences in $C: P_{\text {ext }}$ at 10 and $30 \mathrm{~cm}$ across age classes. The soil-extractable $\mathrm{N}: \mathrm{P}$ ratios $\left(N: P_{\text {ext }}\right)$ showed no variation between the age classes at 5 and $30 \mathrm{~cm}$ depth, while at $10 \mathrm{~cm}$ the $N: P_{\text {ext }}$ ratios increased with the time since the last wildfire (Table 2).

The microbial C:N ratios remained constant across different age classes despite an increase in the soilextractable $\mathrm{C}: \mathrm{N}$ ratio over time following a wildfire (Table 2). However, the microbial C:P ratios were significantly higher at depths of 5 and $10 \mathrm{~cm} 46$ years following a wildfire (Table 2). The microbial N:P ratios showed no significant difference across age classes in the topsoil layers. The microbial $\mathrm{C}: \mathrm{P}$ at $30 \mathrm{~cm}$ was unavailable since the microbial $\mathrm{P}$ therein fell under the detection limit using the ammonium molybdate-malachite green method (see "Soil and microbial biomass $\mathrm{C}, \mathrm{N}$, and $\mathrm{P}$ measurements" section). 
Table 1 Final mixed-effect models of the microbial biomass C, N and P contents and the fungal-to-bacterial ratio (F:B)

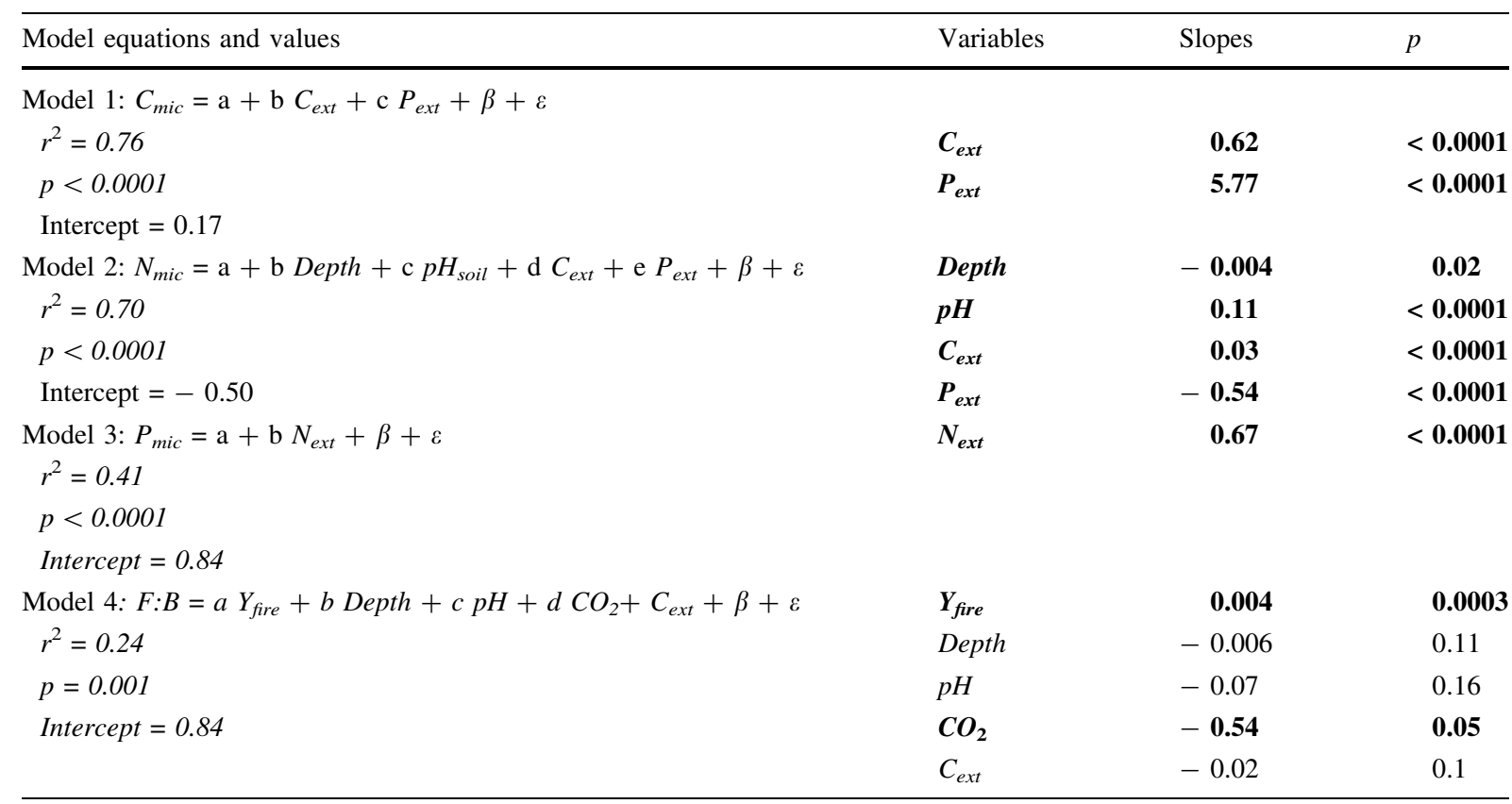

$Y_{\text {fire }}$, years since the last fire, Depth soil depth, $p H$ soil pH, $\mathrm{CO}_{2} \mathrm{CO}_{2}$ fluxes, $C_{\text {ext }}, N_{\text {ext }}$, and $P_{\text {ext }}$ refer to the soil-extractable C, N, and $\mathrm{P}$ contents, respectively; microbial biomass $\mathrm{C}\left(C_{\text {mic }}\right), \mathrm{N}\left(N_{\text {mic }}\right)$, and $\mathrm{P}\left(P_{\text {mic }}\right)$ contents; $\beta$ is the random effect; $\varepsilon$ is the residual. Only variables remained in the final mixed-effect models were shown. Slopes and $p$ values indicate the level of correlation and significance of each variable. The significant explanatory variables were marked in bold

Table 2 Summarized molar C:N, C:P, and N:P ratios and C:N:P stoichiometry for soil extractable elements and soil microbial biomass at each layer in each age area

\begin{tabular}{|c|c|c|c|c|c|c|c|c|c|}
\hline \multirow{2}{*}{$\begin{array}{l}\text { Soil } \\
\text { depths }\end{array}$} & \multirow[t]{2}{*}{ Area } & \multicolumn{4}{|l|}{ Soil } & \multicolumn{4}{|c|}{ Microbial biomass } \\
\hline & & $C: N_{e x t}$ & $C: P_{e x t}$ & $N: P_{e x t}$ & $C: N: P_{e x t}$ & $C: N_{m i c}$ & $C: P_{m i c}$ & $N: P_{m i c}$ & $C: N: P_{m i c}$ \\
\hline \multirow{4}{*}{$\begin{array}{l}5 \mathrm{~cm} \\
\text { layer }\end{array}$} & 2012 & $6.9 \pm 3.4^{\mathrm{a}}$ & $21.6 \pm 16.4^{\mathrm{a}}$ & $3.4 \pm 2.3^{\mathrm{a}}$ & $22: 3: 1$ & $12.5 \pm 4.7^{\mathrm{a}}$ & $25.2 \pm 9.6^{\mathrm{a}}$ & $5.1 \pm 7.9^{\mathrm{a}}$ & $25: 5: 1$ \\
\hline & 1990 & $12.4 \pm 8.9^{\mathrm{a}}$ & $26.8 \pm 17.4^{\mathrm{a}}$ & $2.9 \pm 1.9^{\mathrm{a}}$ & $27: 3: 1$ & $12.8 \pm 4.6^{\mathrm{a}}$ & $39.7 \pm 25.3^{\mathrm{a}}$ & $4.7 \pm 5.10^{\mathrm{a}}$ & $40: 5: 1$ \\
\hline & 1969 & $22.0 \pm 7.8^{\mathrm{b}}$ & $43.7 \pm 12.8^{b}$ & $2.3 \pm 1.3^{\mathrm{a}}$ & $44: 2: 1$ & $13.1 \pm 4.8^{\mathrm{a}}$ & $106.0 \pm 69.5^{\mathrm{b}}$ & $7.8 \pm 7.9^{\mathrm{a}}$ & $106: 8: 1$ \\
\hline & Control & $31.9 \pm 13.3^{\mathrm{b}}$ & $102.8 \pm 79.0^{\mathrm{b}}$ & $4.0 \pm 2.2^{\mathrm{a}}$ & $102: 4: 1$ & $13.1 \pm 7.8^{\mathrm{a}}$ & $39.9 \pm 31.3^{\mathrm{a}}$ & $3.7 \pm 7.6^{\mathrm{a}}$ & $40: 4: 1$ \\
\hline \multirow{4}{*}{$\begin{array}{r}10 \mathrm{~cm} \\
\text { layer }\end{array}$} & 2012 & $9.2 \pm 2.9^{\mathrm{a}}$ & $10.8 \pm 3.7^{\mathrm{a}}$ & $1.2 \pm 0.4^{\mathrm{a}}$ & $11: 1: 1$ & $13.5 \pm 3.8^{\mathrm{a}}$ & $24.9 \pm 23.3^{\mathrm{a}}$ & $1.8 \pm 3.5^{\mathrm{a}}$ & $25: 2: 1$ \\
\hline & 1990 & $13.1 \pm 6.4^{\mathrm{a}}$ & $16.8 \pm 10.8^{\mathrm{a}}$ & $1.4 \pm 1.1^{\mathrm{a}}$ & $17: 1: 1$ & $18.7 \pm 11.5^{\mathrm{a}}$ & $25.0 \pm 19.6^{\mathrm{a}}$ & $0.2 \pm 0.4^{\mathrm{a}}$ & $125: 1: 1$ \\
\hline & 1969 & $22.1 \pm 5.4^{\mathrm{b}}$ & $35.7 \pm 8.4^{\mathrm{b}}$ & $2.3 \pm 1.4^{\mathrm{b}}$ & $36: 2: 1$ & $14.6 \pm 5.1^{\mathrm{a}}$ & $91.1 \pm 4.6^{\mathrm{b}}$ & $3.7 \pm 4.3^{\mathrm{a}}$ & $91: 4: 1$ \\
\hline & Control & $17.6 \pm 9.1^{\mathrm{b}}$ & $33.2 \pm 28.7^{\mathrm{b}}$ & $2.3 \pm 1.4^{\mathrm{b}}$ & $33: 2: 1$ & $12.4 \pm 7.9^{\mathrm{a}}$ & $26.4 \pm 21.1^{\mathrm{a}}$ & $4.3 \pm 4.6^{\mathrm{a}}$ & $26: 4: 1$ \\
\hline \multirow{4}{*}{$\begin{array}{l}30 \mathrm{~cm} \\
\text { layer }\end{array}$} & 2012 & $15.2 \pm 7.0^{\mathrm{a}}$ & $24.0 \pm 3.7^{\mathrm{a}}$ & $1.9 \pm 1.8^{\mathrm{a}}$ & $24: 2: 1$ & $9.0 \pm 2.1^{\mathrm{a}}$ & - & - & - \\
\hline & 1990 & $9.1 \pm 3.8^{\mathrm{a}}$ & $17.4 \pm 13.9^{\mathrm{a}}$ & $2.3 \pm 1.9^{\mathrm{a}}$ & $17: 2: 1$ & $15.0 \pm 6.8^{\mathrm{a}}$ & - & - & - \\
\hline & 1969 & $24.2 \pm 7.6^{\mathrm{b}}$ & $25.1 \pm 5.3^{\mathrm{a}}$ & $1.1 \pm 0.3^{\mathrm{a}}$ & $25: 1: 1$ & $17.0 \pm 6.2^{\mathrm{a}}$ & - & - & - \\
\hline & Control & $11.7 \pm 7.0^{\mathrm{a}}$ & $28.7 \pm 10.3^{\mathrm{a}}$ & $3.2 \pm 2.2^{\mathrm{a}}$ & $29: 3: 1$ & $14.4 \pm 7.3^{\mathrm{a}}$ & - & - & - \\
\hline
\end{tabular}

The data are presented as the mean and standard deviation. The different superscript letters in each soil-depth group means significant difference at a significant level of $p=0.05$. It should be noted that the microbial C:P, N:P, and C:N:P ratios for the 30-cm layers are not shown due to the insufficient available data for $P_{\text {mic }}$

"-_ Indicates data are unavailable 
The fungal:bacterial-ratio and microbial C:N:P stoichiometry

The fungal $18 \mathrm{~S}$ gene copy numbers at $5 \mathrm{~cm}$ were significantly lower $(p<0.05)$ in the younger age classes compared with the control sites (Fig. 3b). However, we found no differences in the fungal $18 \mathrm{~S}$ gene copy numbers at 10 and $30 \mathrm{~cm}$ depths between the age classes. We found no difference in the bacterial $16 \mathrm{~S}$ gene copy numbers between the age classes in any of the soil layers (Fig. 3c).

The fungal-to-bacterial ratios (F:B ratios) were calculated using the ratio between the fungal $18 \mathrm{~S}$ and bacterial 16S gene copy numbers. Quantitative PCR cannot provide an estimation of the $\mathrm{F}$ :B biomass ratio since different taxa contain an unknown number of copies of the rDNA operon in their genomes. However, it provides information on differences between the relative abundance of fungi and bacteria across samples (Fierer et al. 2005). The F:B copy number ratios were significantly lower $(p<0.02)$ in the topsoil (at depths of 5 and $10 \mathrm{~cm}$ ) of the younger age classes compared with those in the control sites (Fig. 3a). However, we found no difference between the age classes at $30 \mathrm{~cm}$. We observed a decreasing trend in the F:B ratios along with the soil depths, indicating a smaller proportion of fungi compared with bacteria in the deep layer. An examination of the mixed-effect model revealed that the $F: B$ ratios were positively correlated with years following a wildfire $(p<0.001)$ and negatively correlated with $\mathrm{CO}_{2}$ emissions $(p=$ 0.05) (Model 4, Table 1). Since the tree and ground vegetation biomasses were highly correlated with the forest age (Fig. S1), the F:B ratios were also highly correlated with the tree and ground vegetation biomass as well.

While the soil-extractable $\mathrm{C}: \mathrm{N}$ and $\mathrm{C}: \mathrm{P}$ ratios showed a consistent trend with the F:B ratio (Fig. 3, Table 2), these did not directly explain the F:B variations in the model (Table S3, Model S6), similar to the total soil C:N ratios (Table S3, Model S5). The microbial $\mathrm{C}: \mathrm{N}$ ratios measured indicated that the microbial biomass was fungi dominated (Figure S3). Furthermore, the Fig. S3 shows that within the range of our observed microbial C:N values, the microbial $\mathrm{C}: \mathrm{N}$ ratios only slightly increased following the fungal-to-bacterial biomass ratios. Therefore, our observed microbial biomass $\mathrm{C}: \mathrm{N}$ and $\mathrm{C}: \mathrm{P}$ ratios showed no correlation with the F:B ratio (Fig. 3,
Table 2). In the best model (Model 4), the years following a wildfire, soil depth, $\mathrm{pH}, \mathrm{CO}_{2}$ fluxes, and soil-extractable C combined explained $24 \%$ of the $\mathrm{F}: \mathrm{B}$ ratio (Model 4). Because the years following a wildfire correlated with the tree biomass (see "Materials and methods" section), the tree biomass explains the F:B ratio as well.

\section{Stoichiometric homeostasis}

Equation 2 was applied to predict the degree of homeostasis (H-value, see Eq. 2). The slopes of the regression lines between the $\mathrm{C}: \mathrm{N}$ and $\mathrm{N}: \mathrm{P}$ ratios of the microbes and that of the soil were referred to as the reciprocal of the homeostatic value $(1 / \mathrm{H})$, and calculated as 0.03 and 0.1 , respectively. These values indicate a high homeostatic regulation (H-value of 33 and 10) (Fig. 4a; Table 3). Compared with the C:N and $\mathrm{N}: \mathrm{P}$ ratios, the homeostatic regulation of the microbial C:P ratio was lower, with a slope of 0.45 equalling a $H$-value of 2.2 (Fig. 4b, c, Table 3). Nevertheless, the slope of the regression line on the $\mathrm{C}: \mathrm{P}$ ratios fell below 1 , indicating homeostatic regulation.

\section{Discussion}

Wildfire effects on microbial stoichiometry

Our analysis indicates a relatively constant microbial $\mathrm{C}: \mathrm{N}$ ratio across the wildfire chronosequence. This refutes our hypothesis that a decrease in the microbial $\mathrm{C}: \mathrm{N}$ and $\mathrm{C}: \mathrm{P}$ ratios occurs due to resource limitations in the first few years following a wildfire. We argue that soil microbial communities exhibit a strict homeostasis in both the short- and long-term following wildfires. Thus, disturbed forests appear to behave similarly to relatively undisturbed ecosystems with respect to the homeostatic regulation (Cleveland and Liptzin 2007; Xu et al. 2015). Wildfire-impacted soils had low extractable organic $\mathrm{C}$ and $\mathrm{N}$ contents, indicating a low soil C:N:P supply (Table 2). In fact, the microbial C:N ratios remained unaffected since the $\mathrm{C}$ and $\mathrm{N}$ in the microbial biomass decreased isometrically. A lack of significant variation in the microbial stoichiometric ratios ( $\mathrm{C}: \mathrm{N}, \mathrm{C}: \mathrm{P}$, and $\mathrm{N}: \mathrm{P}$ ) with varying soil-available element ratios (Fig. 4, Table 3) indicates that microbes actively regulate their $\mathrm{C}: \mathrm{N}: \mathrm{P}$ ratio 

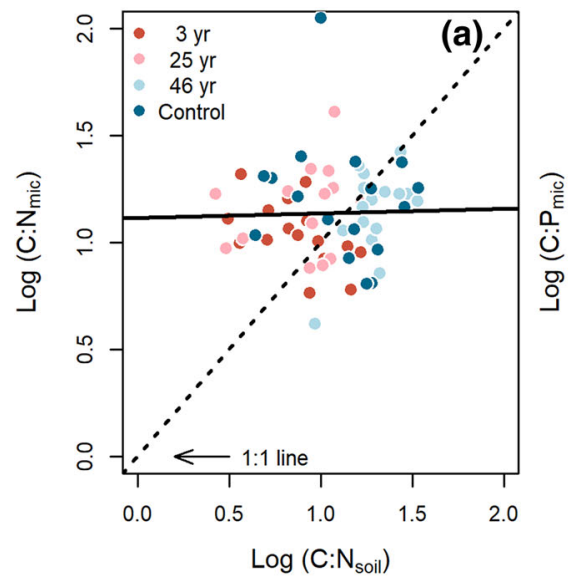
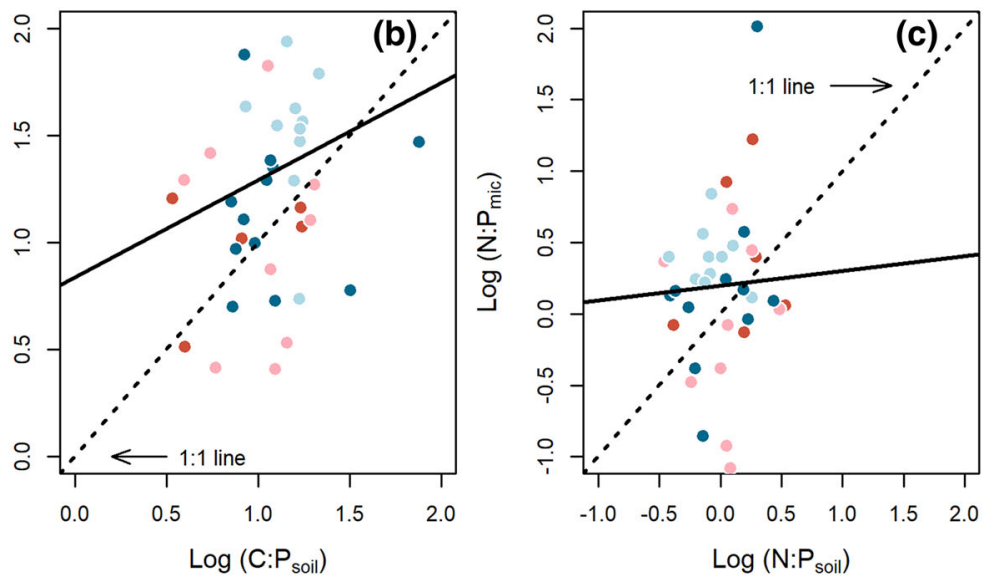

Fig. 4 Regression between the $\mathrm{C}: \mathrm{N}, \mathrm{C}: \mathrm{P}$ and $\mathrm{N}: \mathrm{P}$ ratios measured in microbial biomass and the soil-extractable C:N, $\mathrm{C}: \mathrm{P}$, and $\mathrm{N}: \mathrm{P}$ ratios. The distinct colours represent the areas 3 ,

Table 3 Correlation between the C:N, C:P, and N:P ratios from the microbial biomass and the surrounding soil. $H$ represents the homeostatic degree (reciprocal of the regression slope)

\begin{tabular}{lllllc}
\hline & $r^{2}$ & $t$ value & $p$ & slope & $H$ value \\
\hline$C: N$ & 0.002 & 0.32 & 0.73 & 0.03 & 33.3 \\
$C: P$ & 0.043 & 1.36 & 0.17 & 0.45 & 2.2 \\
$N: P$ & 0.045 & 1.53 & 0.13 & 0.10 & 10.0 \\
\hline
\end{tabular}

even in severely disturbed conditions. The evidence for the strict homeostasis of the $\mathrm{C}: \mathrm{N}$ ratios in our data is convincing. Although the $H$ values of the $\mathrm{C}: \mathrm{P}$ and $\mathrm{N}: \mathrm{P}$ ratios were lower than that of the $\mathrm{C}: \mathrm{N}$, they exceeded 1 . This suggests that microbes carry a less strict homeostatic regulation of their P content. High variation in the microbial $\mathrm{C}: \mathrm{P}$ and $\mathrm{N}: \mathrm{P}$ ratios have been found across different vegetation types (Yeates and Saggar 1998; Cleveland and Liptzin 2007) suggesting that changes in the vegetation cover potentially influence the $\mathrm{C}: \mathrm{P}$ or $\mathrm{N}: \mathrm{P}$ ratios.

The soil microbial communities maintain their stoichiometric ratio by adjusting the elemental use efficiencies. These adjustment mechanisms include mineralization and the release of the excess elements (e.g., N) (Mooshammer et al. 2014) or a shortening turnover time of the excess elements (e.g. P and C) (Russell and Cook 1995; Spohn and Widdig 2017). This, as suggested by the nutrient use efficiency theory (Six et al. 2006), maximizes the use of the limiting
25 , and 46 years since the last fire, and the control area. The dashed lines plot the 1:1 relation

elements including the use of C (Six et al. 2006; Mooshammer et al. 2014). Overflow respiration, a mechanism to adjust stoichiometry by respiring excess $\mathrm{C}$, takes place when microbial growth is nutrientlimited (Tempest and Neijssel 1992; Russell and Cook 1995). These arguments support our observation of higher $\mathrm{CO}_{2}$ emissions and high microbial C:P ratios in the 46-year-old areas (Fig. 1, Table 2).

Past empirical studies demonstrated that the fungal biomass has a higher $\mathrm{C}: \mathrm{N}$ than bacteria (Wallenstein et al. 2006; Mouginot et al. 2014). However, the constrained microbial $\mathrm{C}: \mathrm{N}$ ratio of around $12-14: 1$ found in this study did not respond to increasing $\mathrm{F}: \mathrm{B}$ ratios (Table 2, Fig. 3a). To explain this, we simulated the dynamics of the microbial biomass $\mathrm{C}: \mathrm{N}$ ratio along with a gradient of the F:B biomass ratio (Fig. S3 and Methods). In our model, we demonstrated how the microbial $\mathrm{C}: \mathrm{N}$ ratios respond to the $\mathrm{F}: \mathrm{B}$ ratios with a given fungal biomass $\mathrm{C}: \mathrm{N}$ of 16 and bacterial $\mathrm{C}: \mathrm{N}$ of 6 (Wallenstein et al. 2006; Waring et al. 2013) (see "Materials and methods" section). We showed that the largest change in the $\mathrm{F}: \mathrm{B}$ ratio took place between the microbial biomass $\mathrm{C}: \mathrm{N}$ ratios of 12 to 14 and the microbial $\mathrm{C}: \mathrm{N}$ ratio levelled off around 14 when the F:B ratio increased from 5-20 (Fig. S3). Therefore, the microbial $\mathrm{C}: \mathrm{N}$ ratio can be considered as constrained (12-14:1) when the F:B biomass ratio exceeded 5. A recent study showed that the microbial $\mathrm{C}: \mathrm{N}$ and $\mathrm{C}: \mathrm{P}$ ratios positively correlated with the $\mathrm{F}: \mathrm{B}$ ratio (Chen et al. 2016), but its F:B ratio only explained $3-5 \%\left(r^{2}=\right.$ $0.03-0.05)$ of the $\mathrm{C}: \mathrm{N}$ and $\mathrm{C}: \mathrm{P}$ variation. 
The F:B gene ratios ranged from 0.004 to 0.6 , similar to the $\mathrm{F}: \mathrm{B}$ ratios in studies applying the same approach (Boyle et al. 2008; Nemergut et al. 2008; Fierer et al. 2009). This implies that the bacterial gene copy number always exceeds the fungal. The amount of the fungal gene copy number per gram of soil after a wildfire was significantly lower than that in the control areas, while we found no difference in the amount of the bacterial gene copy number between the age classes. This suggests that the effect of wildfire on the fungal biomass was pronounced, while a wildfire had little effect on the bacterial biomass. We argue that the losses of mycorrhizal fungi due to the loss of vegetation may serve as the primary driver of the changes in the fungal biomass we observed. Our results suggest that the recovery of soil fungi from a forest wildfire requires at least 46 years, while the recovery of the bacterial biomass may require less than 3 years. This conclusion is consistent with a shortterm heating experiment, which showed that bacteria are more tolerant to heat and recover from heat much faster than fungi (Bárcenas-Moreno and Bååth 2009). Wildfire decreased both the microbial biomass and $\mathrm{F}: \mathrm{B}$ ratio in the topsoil layers (Fig. 3). The soil pH, tree biomass and soil-available $\mathrm{C}$ explained $24 \%$ of the F:B changes (Model 4, Table 1), consistent with a previous study showing that soil $\mathrm{pH}$ adversely affected the F:B ratio (Bååth and Anderson 2003). While some global-scale studies found a high correlation between the F:B and soil C:N ratios (Fierer et al. 2009; Waring et al. 2013), we only found a weak link. One possible reason lies in the variation of soil stoichiometry in our study carried out in a boreal forest limited to a smaller range, resulting in a low correlation between the soil $\mathrm{C}: \mathrm{N}$ and $\mathrm{F}: \mathrm{B}$ ratios. It is worth noting that the bacterial biomass could indeed be changing, although the bacterial $16 \mathrm{~S}$ gene copy numbers largely remain the same across the different stages of post-fire succession. Previous studies demonstrated that early successional bacterial communities have higher 16S copy numbers (Nemergut et al. 2016; Ortiz-Álvarez et al. 2018). Therefore, the bacterial biomass in this study may have increased with time after a wildfire, although we observed similar $16 \mathrm{~S}$ gene abundances at different stand ages (Fig. 3).
Wildfire effects along the soil depth profile

Despite wildfire tremendously affecting soil microbes in the topsoil layers, it did not affect those at a depth of $30 \mathrm{~cm}$. It is well established that wildfire reduces the microbial biomass (Dooley and Treseder 2012; Köster et al. 2014) and alters microbial decomposition at the soil surface (Coolen et al. 2011). However, studies on microbes focusing on deeper soil layers, particularly in permafrost, remain rare. We hypothesized that recently burned areas would exhibit a higher microbial biomass in the deeper soil layers than the older areas because the soil temperature and the depth of the active layer increased significantly following a wildfire (Köster et al. 2017). However, wildfires had no influence on the soil microbial biomass and the microbial C:N ratio at the depth of $30 \mathrm{~cm}$ (Fig. 2, Table 2). Although microbial $\mathrm{C}$ decreased with the soil depth, wildfire effects appeared pronounced at the soil surface, but absent in the deeper soil layers. By contrast, reductions in soil resources, especially extractable organic $\mathrm{C}$, substantially affected microbial C stocks. Our mixed-effect model revealed that $76 \%$ of the microbial $\mathrm{C}$ was explained by soil-extractable $\mathrm{C}$ and $\mathrm{P}$ (Table 1). The constrained microbial $\mathrm{C}: \mathrm{N}$ ratio with the soil depth demonstrates that microbes in northern boreal forest soils retain strict homeostasis under low energy and nutrient availability conditions.

Microbial communities in the deep soil layers are typically dominated by bacteria (Zhang et al. 2016). Our results from the control sites confirmed this and revealed a gradually decreasing $\mathrm{F}: \mathrm{B}$ ratio with the soil depth. We also found no difference in the F:B ratios and microbial biomasses at the depth of $30 \mathrm{~cm}$ across age classes indicating that wildfire and permafrost thawing did not activate microbes in deeper soil layers. The mixed-effect model (Model 4) showed that soil extractable C increased the F:B ratio (Model 4, Table 1). This likely results from the difficulty in saprotrophs colonizing the lower soil in the 3-and 25-year-old sites because of the low soil organic C supply (Baldrian 2009). Thus, when lacking an appropriate substrate, soil fungal (and perhaps bacterial) communities in the 3-and 25-year-old sites might have lowered their metabolic activity, and were perhaps present in a dormant state. At 25 years following a fire, $C_{\text {soil }}, C_{m i c}$, as well as trees and ground vegetation, began regenerating (see Fig. 1b). The regenerating vegetation may support the fungal 
growth in the soil by providing the substrate for the saprotrophs in the form of litterfall, and for the ectomycorrhizae in the form of photosynthate. However, the impact of a wildfire on microbes in the deeper soil layers was not overall statistically significant.

\section{Implications for $\mathrm{N}$ and $\mathrm{P}$ cycling}

The mixed-model results indicate that the microbial biomass $\mathrm{N}$ cannot be explained by the soil-extractable $\mathrm{N}$. Instead, the microbial biomass $\mathrm{N}$ positively correlated with soil $\mathrm{pH}$ and soil-extractable $\mathrm{C}$. The effect of extractable $\mathrm{C}$ on microbial $\mathrm{N}$ and $\mathrm{C}$ indicates that microbes in our wildfire-impacted soil were C-limited. We found no difference in the soilextractable $\mathrm{P}$ in the soil surface of the burned areas compared with the control area (Fig. 2). $\mathrm{P}$ is derived only from the weathering of soil minerals and bedrocks, unlike $\mathrm{C}$ and $\mathrm{N}$ that originate primarily from the atmosphere. Furthermore, $\mathrm{P}$ is a noncombustible element and tends to accumulate at the soil surface following a wildfire (Burke et al. 2005), where it can be easily lost to runoff. However, the low inorganic $\mathrm{P}$ content of the soil in the oldest areas implies that $\mathrm{P}$ might have become depleted or bound to a more stable form or been stored in the tree and ground vegetation biomass following long-term succession (Vitousek and Farrington 1997). Surprisingly, we detected higher amounts of inorganic $\mathrm{P}$ in the deep soil of the control areas than in the recently burnt areas. This likely results from samples collected from the $30-\mathrm{cm}$ layer stemming from permafrost, where $\mathrm{P}$ cannot be lost to leaching.

Furthermore and rather surprisingly, in our statistical models soil-extractable $\mathrm{P}$ predicted the microbial biomass as well as the microbial N. One explanation stems from $\mathrm{P}$ availability limiting microbial biomass. Boreal forest soils are usually young and rich in $\mathrm{P}$ that should be unnecessarily a limiting nutrient for microbes, while old soils, such as those in tropical ecosystems, are $\mathrm{P}$ depleted (Parfitt et al. 2005). However, our study areas were not glaciated during the last ice age, and the soil ages are thus much higher than average in a boreal region (Yukon Ecoregions Working Group 2004). Therefore, it might be possible that $\mathrm{P}$ plays a more limiting role or that the inorganic $\mathrm{P}$ contents correlate with other unmeasured soil factors (such as properties linked to the bioavailability of soil organic matter), which we failed to measure.
Nevertheless, this work is consistent with emerging research demonstrating that $\mathrm{P}$ prevails in nutrientlimiting and controls the microbial community structure and succession (Knelman et al. 2014).

\section{Conclusions}

Forest wildfire increased the active layer depth and subsequently decreased soil moisture and vegetation coverage. This consequently led to a decrease in the microbial $\mathrm{C}$ and $\mathrm{N}$ contents as well as the $\mathrm{F}: \mathrm{B}$ ratios. However, the $\mathrm{C}: \mathrm{N}: \mathrm{P}$ ratios in the microbial biomass remained relatively constant over time following a wildfire, indicating homeostatic regulation. Wildfire failed to affect the microbial communities in the deepsoil layers, although the soil temperature and moisture had changed. These results indicate a complex interaction between the decomposer community, resource availability, and successional stage. This interaction should be explored in greater detail using molecular biological and modelling approaches. Forest wildfire either shifted the microbial diversity or suppressed the microbial growth rate for several decades. The underlying changes in the microbial community composition warrant further exploration.

Acknowledgements This study was supported Grants from the Academy of Finland [Grant Numbers 286685, 294600, 307222]. HS was supported by Jiangsu Specially-Appointed Professor (project 165010015) and Priority Academic Program Development of Jiangsu Higher Education Institutions (PAPD). $\mathrm{XZ}$ was supported by a grant from the Chinese Scholarship Council. We would like to thank Saara Berninger for patient help in the field, Xuan Yu for assistance with genomic DNA extraction, Marjut Wallner for technical assistance in laboratory help and Mike Starr for his valuable advice on P measurements. We wish to thank David Fewer and Vanessa L Fuller for the language revision.

Open Access This article is distributed under the terms of the Creative Commons Attribution 4.0 International License (http:// creativecommons.org/licenses/by/4.0/), which permits unrestricted use, distribution, and reproduction in any medium, provided you give appropriate credit to the original author(s) and the source, provide a link to the Creative Commons license, and indicate if changes were made. 


\section{References}

Akaike H (1998) Information theory and an extension of the maximum likelihood principle. In: Parzen E, Tanabe K, Kitagawa G (eds) BT-selected papers of Hirotugu Akaike. Springer, New York, pp 199-213

Allison SD, Lu Y, Weihe C et al (2013) Microbial abundance and composition influence litter decomposition response to environmental change. Ecology 94:714-725. https://doi. org/10.1890/12-1243.1

Bååth E, Anderson TH (2003) Comparison of soil fungal/bacterial ratios in a $\mathrm{pH}$ gradient using physiological and PLFA-based techniques. Soil Biol Biochem 35:955-963. https://doi.org/10.1016/s0038-0717(03)00154-8

Bååth E, Frostegård Å, Pennanen T, Fritze H (1995) Microbial community structure and $\mathrm{pH}$ response in relation to soil organic matter quality in wood-ash fertilized, clear-cut or burned coniferous forest soils. Soil Biol Biochem 27: 229-240. https://doi.org/10.1016/0038-0717(94)00140-v

Baldrian P (2009) Ectomycorrhizal fungi and their enzymes in soils: is there enough evidence for their role as facultative soil saprotrophs? Oecologia 161:657-660. https://doi.org/ 10.1007/s00442-009-1433-7

Bárcenas-Moreno G, Bååth E (2009) Bacterial and fungal growth in soil heated at different temperatures to simulate a range of fire intensities. Soil Biol Biochem 41:2517-2526. https://doi.org/10.1016/j.soilbio.2009.09.010

Beck T, Joergensen RG, Kandeler E et al (1997) An inter-laboratory comparison of ten different ways of measuring soil microbial biomass C. Soil Biol Biochem 29:1023-1032. https://doi.org/10.1016/s0038-0717(97)00030-8

Betes D, Machler M, Bolker B, Walker S (2015) Fitting linear mixed-effects models using \{lme4\}. J Stat Softw 67:1-48

Boyle SA, Yarwood RR, Bottomley PJ, Myrold DD (2008) Bacterial and fungal contributions to soil nitrogen cycling under Douglas fir and red alder at two sites in Oregon. Soil Biol Biochem 40:443-451. https://doi.org/10.1016/j. soilbio.2007.09.007

Brookes PC, Powlson DS, Jenkinson DS (1982) Measurement of microbial biomass phosphorus in soil. Soil Biol Biochem 14:319-329. https://doi.org/10.1016/0038-0717(82)900 01-3

Brookes PC, Landman A, Pruden G, Jenkinson DS (1985) Chloroform fumigation and the release of soil nitrogen: a rapid direct extraction method to measure microbial biomass nitrogen in soil. Soil Biol Biochem 17:837-842. https://doi.org/10.1016/0038-0717(85)90144-0

Brown MB, Forsythe AB (1974) Robust tests for the equality of variances. J Am Stat Assoc 69:364-367. https://doi.org/10. 1080/01621459.1974.10482955

Burke JM, Prepas EE, Pinder S (2005) Runoff and phosphorus export patterns in large forested watersheds on the western Canadian Boreal Plain before and for 4 years after wildfire. J Environ Eng Sci 4:319-325. https://doi.org/10.1139/s04072

Chambers JM, Hastie TJ (1992) Chapter 4 of statistical models in S. In: Linear models. Wadsworth \& Brooks/Cole, Pacific Grove

Chen YL, Chen LY, Peng YF et al (2016) Linking microbial $\mathrm{C}: \mathrm{N}$ : P stoichiometry to microbial community and abiotic factors along a 3500-km grassland transect on the Tibetan Plateau. Glob Ecol Biogeogr 25:1416-1427. https://doi. org/10.1111/geb. 12500

Cleveland CC, Liptzin D (2007) C:N: P stoichiometry in soil: is there a "Redfield ratio" for the microbial biomass? Biogeochemistry 85:235-252. https://doi.org/10.1007/ s10533-007-9132-0

Coolen MJL, van de Giessen J, Zhu EY, Wuchter C (2011) Bioavailability of soil organic matter and microbial community dynamics upon permafrost thaw. Environ Microbiol 13:2299-2314. https://doi.org/10.1111/j.1462-2920. 2011.02489.x

D’Angelo E, Crutchfield J, Vandiviere M (2001) Rapid, sensitive, microscale determination of phosphate in water and soil. J Environ Qual 30:2206-2209. https://doi.org/10. 2134/jeq2001.2206

Debano LF (2000) The role of fire and soil heating on water repellency in wildland environments: a review. J Hydrol 231-232:195-206. https://doi.org/10.1016/s00221694(00)00194-3

Dooley SR, Treseder KK (2012) The effect of fire on microbial biomass: a meta-analysis of field studies. Biogeochemistry 109:49-61. https://doi.org/10.1007/s10533-011-9633-8

Fanin N, Fromin N, Buatois B, Hättenschwiler S (2013) An experimental test of the hypothesis of non-homeostatic consumer stoichiometry in a plant litter-microbe system. Ecol Lett 16:764-772. https://doi.org/10.1111/ele.12108

Fierer N, Jackson J (2005) Assessment of soil microbial community structure by use of taxon-specific quantitative PCR assays. Appl Environ Microbiol 71:4117. https://doi.org/ 10.1128/aem.71.7.4117

Fierer N, Jackson J, Vilgalys R, Jackson R (2005) Assessment of soil microbial community structure by use of taxonspecific quantitative PCR assays. Appl Environ Microbiol 71:4117. https://doi.org/10.1128/aem.71.7.4117

Fierer N, Strickland MS, Liptzin D et al (2009) Global patterns in belowground communities. Ecol Lett 12:1238-1249. https://doi.org/10.1111/j.1461-0248.2009.01360.x

Gill HK, Lantzx TC, O’Neill B, Kokelj SV (2014) Cumulative impacts and feedbacks of a gravel road on Shrub Tundra ecosystems in the Peel Plateau, Northwest Territories, Canada. Arctic Antarct Alp Res 46:947-961. https://doi. org/10.1657/1938-4246-46.4.947

González-Pérez JA, González- FJ, Almendros G, Knicker H (2004) The effect of fire on soil organic matter-a review. Environ Int 30:855-870. https://doi.org/10.1016/j.envint. 2004.02.003

Government of Yukon (2011) GeoYukon. In: Gov. Yukon

Griffiths BS, Spilles A, Bonkowski M (2012) C:N: P stoichiometry and nutrient limitation of the soil microbial biomass in a grazed grassland site under experimental $\mathrm{P}$ limitation or excess. Ecol Process 1:6. https://doi.org/10. 1186/2192-1709-1-6

Harden JW, Neff JC, Sandberg DV et al (2004) Chemistry of burning the forest floor during the FROSTFIRE experimental burn, interior Alaska, 1999. Glob Biogeochem Cycles. https://doi.org/10.1029/2003gb002194

Hedley MJ, Stewart JWB (1982) Method to measure microbial phosphate in soils. Soil Biol Biochem 14:377-385. https:// doi.org/10.1016/0038-0717(82)90009-8 
Helin A, Sietiö OM, Heinonsalo J et al (2017) Characterization of free amino acids, bacteria and fungi in size-segregated atmospheric aerosols in boreal forest: seasonal patterns, abundances and size distributions. Atmos Chem Phys 17:13089-13101. https://doi.org/10.5194/acp-17-130892017

Heuck C, Weig A, Spohn M (2015) Soil microbial biomass C:N: $\mathrm{P}$ stoichiometry and microbial use of organic phosphorus. Soil Biol Biochem 85:119-129. https://doi.org/10.1016/j. soilbio.2015.02.029

Högberg MN, Högberg P, Myrold DD (2007) Is microbial community composition in boreal forest soils determined by $\mathrm{pH}, \mathrm{C}-$ to- $\mathrm{N}$ ratio, the trees, or all three? Oecologia 150:590-601. https://doi.org/10.1007/s00442-006-0562-5

Holden SR, Gutierrez A, Treseder KK (2013) Changes in soil fungal communities, extracellular enzyme activities, and litter decomposition across a fire chronosequence in Alaskan Boreal Forests. Ecosystems 16:34-46. https://doi. org/10.1007/s10021-012-9594-3

James G, Witten D, Hastie T, Tibshirani R (2000) An introduction to statistical learning. Springer, New York

Johnson DW, Curtis PS (2001) Effects of forest management on soil C and N storage: meta analysis. For Ecol Manage 140: 227-238. https://doi.org/10.1016/s0378-1127(00)00282-6

Jonsson L, Dahlberg A, Nilsson MC et al (1999) Ectomycorrhizal fungal communities in late-successional Swedish boreal forests, and their composition following wildfire. Mol Ecol 8:205-215. https://doi.org/10.1046/j.1365-294x. 1999.00553.x

Kasischke ES, Stocks BJ (2000) Fire, climate change, and carbon cycling in the Boreal Forest. Springer, New York

Knelman JE, Schmidt SK, Lynch RC et al (2014) Nutrient addition dramatically accelerates microbial community succession. PLoS ONE. https://doi.org/10.1371/journal. pone.0102609

Knelman JE, Graham EB, Ferrenberg S et al (2017) Rapid shifts in soil nutrients and decomposition enzyme activity in early succession following forest fire. Forests 8(9):347

Knicker H (2007) How does fire affect the nature and stability of soil organic nitrogen and carbon? A review. Biogeochemistry 85:91-118. https://doi.org/10.1007/s10533-0079104-4

Köster K, Berninger F, Lindén A et al (2014) Recovery in fungal biomass is related to decrease in soil organic matter turnover time in a boreal fire chronosequence. Geoderma 235-236:74-82. https://doi.org/10.1016/j.geoderma.2014. 07.001

Köster K, Berninger F, Heinonsalo J et al (2016) The long term impact of forest fires on soil enzyme activities and litter decomposition in the northern boreal coniferous forests. Int J Wildl Fire 25:213-223

Köster E, Köster K, Berninger F et al (2017) Carbon dioxide, methane and nitrous oxide fluxes from a fire chronosequence in subarctic boreal forests of Canada. Sci Total Environ 601-602:895-905. https://doi.org/10.1016/j. geodrs.2015.07.001

Kuuskeri J, Häkkinen M, Laine P et al (2016) Time-scale dynamics of proteome and transcriptome of the white-rot fungus Phlebia radiata: growth on spruce wood and decay effect on lignocellulose. Biotechnol Biofuels 9:1-22. https://doi.org/10.1186/s13068-016-0608-9
Lambert M-C, Ung C-H, Raulier F (2005) Canadian national tree aboveground biomass equations. Can J For Res 35:1996-2018. https://doi.org/10.1139/x05-112

Liu H, Randerson JT, Lindfors J, Chapin FS (2005) Changes in the surface energy budget after fire in boreal ecosystems of interior Alaska: an annual perspective. J Geophys Res Atmos 110:1-12. https://doi.org/10.1029/2004jd005158

Midgley MG, Phillips RP (2016) Resource stoichiometry and the biogeochemical consequences of nitrogen deposition in a mixed deciduous forest. Ecology 97:3369-3377. https:// doi.org/10.1002/ecy.1595

Mooshammer M, Wanek W, Schnecker J et al (2012) Stoichiometric controls of nitrogen and phosphorus cycling in decomposing beech leaf litter. Ecology 93:770-782. https://doi.org/10.1890/11-0721.1

Mooshammer M, Wanek W, Zechmeister-Boltenstern S, Richter A (2014) Stoichiometric imbalances between terrestrial decomposer communities and their resources: mechanisms and implications of microbial adaptations to their resources. Front Microbiol 5:1-10. https://doi.org/10.3389/ fmicb.2014.00022

Mouginot C, Kawamura R, Matulich KL et al (2014) Elemental stoichiometry of fungi and bacteria strains from grassland leaf litter. Soil Biol Biochem 76:278-285. https://doi.org/ 10.1016/j.soilbio.2014.05.011

Nemergut DR, Townsend AR, Sattin SR et al (2008) The effects of chronic nitrogen fertilization on alpine tundra soil microbial communities: implications for carbon and nitrogen cycling. Environ Microbiol 10:3093-3105. https://doi.org/10.1111/j.1462-2920.2008.01735.x

Nemergut DR, Knelman JE, Ferrenberg S et al (2016) Decreases in average bacterial community rRNA operon copy number during succession. ISME J 10:1147-1156. https://doi. org/10.1038/ismej.2015.191

Oksanen J, Blanchet FG, Friendly M, et al (2017) Vegan: Community Ecology Package. https://CRAN.R-project. org/package=vegan

Olsen SR, Cole CV, Watanabe FS, Dean LA (1954) Estimation of available phosphorus in soils by extraction with sodium bicarbonate, pp 18-19

Ortiz-Álvarez R, Fierer N, De Los Ríos A et al (2018) Consistent changes in the taxonomic structure and functional attributes of bacterial communities during primary succession. ISME J 12:1658-1667. https://doi.org/10.1038/s41396018-0076-2

Parfitt RL, Ross DJ, Coomes DA et al (2005) N and P in New Zealand soil chronosequences and relationships with foliar $\mathrm{N}$ and P. Biogeochemistry 75:305-328. https://doi.org/10. 1007/s10533-004-7790-8

Peay KG, Garbelotto M, Bruns TD (2009) Spore heat resistance plays an important role in disturbance-mediated assemblage shift of ectomycorrhizal fungi colonizing Pinus muricata seedlings. J Ecol 97:537-547. https://doi.org/10. 1111/j.1365-2745.2009.01489.x

Redfield A (1958) The biological control of chemical factors in the environment. Am Sci 46:205-221

Redfield AC, Ketchum BH, Richards FA (1963) The Influence of Organisms on the Composition of Sea Water. Hill MN The sea: ideas and observations on progress in the study of the seas. Interscience Publishers, New York, pp 26-77 
Russell JB, Cook GM (1995) Energetics of bacterial growth: balance of anabolic and catabolic reactions. Microbiol Rev 59:48-62

Sarkar D (2008) Lattice: multivariate data visualization with R. Springer, New York

Schimel JP, Bennett J (2004) Nitrogen mineralization: challenges of a changing paradigm. Ecology 85:591-602. https://doi.org/10.1890/03-8002

Schneider R (2007) Effet De L'Eclaircie Commerciale Sur La Croissance Et La Qualité Du Bois Du Pin Gris

Schuur E, Bockheim J, Canadell J (2008) Vulnerability of permafrost carbon to climate change: implications for the global carbon cycle. Bioscience 58:701-714

Shapiro ASS, Wilk MB (1965) Biometrika trust an analysis of variance test for normality (Complete Samples). Biometrika 52:591-611

Singh BK, Bardgett RD, Smith P, Reay DS (2010) Microorganisms and climate change: terrestrial feedbacks and mitigation options. Nat Rev Microbiol 8:779-790. https:// doi.org/10.1038/nrmicro2439

Six J, Frey SD, Thiet RK, Batten KM (2006) Bacterial and fungal contributions to carbon sequestration in agroecosystems. Soil Sci Soc Am J 70:555. https://doi.org/10. 2136/sssaj2004.0347

Spohn M, Widdig M (2017) Turnover of carbon and phosphorus in the microbial biomass depending on phosphorus availability. Soil Biol Biochem 113:53-59. https://doi.org/10. 1016/j.soilbio.2017.05.017

Stanek W (1982) Reconnaissance of vegetation and soils along the dempster highway, Yukon Territory: II. Soil properties as related to revegetation. In: PacificForest Res Cent (ed) Can For Serv no BC-X-236 Can Canadian Forestry Service, Victoria, p 34

Sterner RW, Elser JJ (1992) Stoichiometric relationships among producers, consumers and nutrient cycling in pelagic ecosystems. Biogeochemistry 17(1):49-67

Sterner RW, Elser JJ (2002) Ecological stoichiometry. Princeton University Press, Princeton

Strickland MS, Rousk J (2010) Considering fungal: bacterial dominance in soils-methods, controls, and ecosystem implications. Soil Biol Biochem 42:1385-1395. https:// doi.org/10.1016/j.soilbio.2010.05.007

Sun H, Santalahti M, Pumpanen J et al (2015) Fungal community shifts in structure and function across a Boreal Forest Fire Chronosequence. Appl Environ Microbiol 81:78697880. https://doi.org/10.1128/aem.02063-15.editor

Taş N, Prestat E, McFarland JW et al (2014) Impact of fire on active layer and permafrost microbial communities and metagenomes in an upland Alaskan boreal forest. ISME J 8(9):1904-1919. https://doi.org/10.1038/ismej.2014.36

Tempest DW, Neijssel OM (1992) Physiological and energetic aspects of bacterial metabolite overproduction. FEMS Microbiol Lett 100:169-176. https://doi.org/10.1016/ 0378-1097(92)90205-3

Treseder KK, Mack MC, Cross A (2012) Relationships among fires, fungi, and soil dynamics in Alaskan Boreal Forests. Ecol Appl 14:1826-1838
Vainio EJ, Hantula J (2000) Direct analysis of wood-inhabiting fungi using denaturing gradient gel electrophoresis of amplified ribosomal DNA. Mycol Res 104:927-936. https://doi.org/10.1017/s0953756200002471

Vitousek P, Farrington H (1997) Nutrient limitation and soil development: experimental test of a biogeochemical theory. Biogeochemistry 37:63-75

Wagner RG, Ter-Mikaelian MT (1999) Comparison of biomass component equations for four species of northern coniferous tree seedlings. Ann For Sci 56:193-199. https://doi. org/10.1051/forest:19990301

Wallenstein MD, McNulty S, Fernandez IJ et al (2006) Nitrogen fertilization decreases forest soil fungal and bacterial biomass in three long-term experiments. For Ecol Manage 222:459-468. https://doi.org/10.1016/j.foreco.2005.11. 002

Wan S, Hui D, Luo Y (2001) Fire effects on nitrogen pools and dynamics in terrestrial ecosystems: a meta-analysis. Ecol Appl 11:1349-1365. https://doi.org/10.1890/10510761(2001)011\%5b1349:feonpa\%5d2.0.co;2

Waring BG, Averill C, Hawkes CV (2013) Differences in fungal and bacterial physiology alter soil carbon and nitrogen cycling: insights from meta-analysis and theoretical models. Ecol Lett 16:887-894. https://doi.org/10.1111/ele. 12125

Wickham H (2009) ggplot2: elegant graphics for data analysis. Springer-Verlag, New York

Wilkinson JF (1963) Carbon and energy storage in Bacteria. J Gen Microbiol 32:171-176. https://doi.org/10.1099/ 00221287-32-2-171

World Weather Online (2016) Historical average weather. In: World Weather Online

Xu X, Thornton PE, Post WM (2013) A global analysis of soil microbial biomass carbon, nitrogen and phosphorus in terrestrial ecosystems. Glob Ecol Biogeogr 22:737-749. https://doi.org/10.1111/geb.12029

Xu X, Hui D, King AW et al (2015) Convergence of microbial assimilations of soil carbon, nitrogen, phosphorus, and sulfur in terrestrial ecosystems. Sci Rep 5:17445. https:// doi.org/10.1038/srep17445

Yeates GW, Saggar S (1998) Comparison of soil microbial properties and fauna under tussock-grassland and pine plantation. J R Soc New Zeal 28:523-535. https://doi.org/ 10.1080/03014223.1998.9517574

Yukon Ecoregions Working Group (2004) Boreal Cordillera Ecozone

Zhang Q, Wu J, Yang F et al (2016) Alterations in soil microbial community composition and biomass following agricultural land use change. Sci Rep 6:36587. https://doi.org/10. 1038/srep36587

Zhou Z, Wang C, Jin Y (2017) Stoichiometric responses of soil microflora to nutrient additions for two temperate forest soils. Biol Fertil Soils 53:397-406. https://doi.org/10.1007/ s00374-017-1188-y 